\title{
Spatial Distribution of Shoot Fly, Atherigona soccata (Rondani) on Sorghum with Respect to Different Dates of Sowing
}

\author{
Dilbag Singh Ahlawat ${ }^{1 *} \&$ Dalip Kumar ${ }^{2}$ \\ ${ }^{1}$ CCS HAU, Regional Research Station, Rohtak-124001, India. E-mail: ahlawatento@gmail.com* \\ ${ }^{2}$ Department of Entomology, CCS HAU, Hisar-125004, India.
}

DOI: http://doi.org/10.38177/ajast.2021.5309

Copyright: @ 2021 Dilbag Singh Ahlawat \& Dalip Kumar. This is an open access article distributed under the terms of the Creative Commons Attribution License, which permits unrestricted use, distribution, and reproduction in any medium, provided the original author and source are credited.

\section{AB STR ACT}

An investigation was carried out to know the incidence of shoot fly on sorghum during year 2018 and 2019 in Kharif season at Research farm, CCS Haryana Agricultural University, Regional Research Station, Rohtak (India). Incidence of shoot fly was found to be higher in $15^{\text {th }}$ to $30^{\text {th }} \mathrm{July}$ sown crops. It is evident from the pooled data for both the years (2018 and 2019) that the crop sown on $15^{\text {th }}$ June, showed significantly lowest per cent of dead heart incidence (5.20 and 8.00 (pooled) by shoot fly at $14^{\text {th }}$ and $28^{\text {th }}$ days after crop emergence, respectively. Whereas, the crop sown on $30^{\text {th }}$ July, 2018-19 showed significantly higher per cent of dead heart incidence i.e., 21.60 and 32.80 (pooled) at $14^{\text {th }}$ and $28^{\text {th }}$ days after crop emergence, respectively. Significantly, maximum yield of $10.82 \mathrm{q} /$ ha was obtained in case of crop sown on $15^{\text {th }}$ June, while lowest yield of $2.24 \mathrm{q} /$ ha when crop sown on $30^{\text {th }} \mathrm{July}$. As the sowing was delayed beyond $30^{\text {th }}$ June the incidence increased while yield decreased significantly. In the present study, it was found as the sowing was delayed the shoot fly incidence increased and the grain yield decreased.

Keywords: Sorghum, Shoot fly, Incidence, Seed yield, Sowing date.

\section{Introduction}

Sorghum [Sorghum bicolor (Linn.) Moench] is one of the most important cereal for human food and animal feed crops of the world particularly in the developing world, adapted to a wide range of ecological conditions and includes both cultivated and wild species, suitability for low input cultivation and diverse uses (Doggett, 1970). Sorghum yields are pathetically low ranging from 500 to $800 \mathrm{~kg} / \mathrm{ha}$ in Africa and Asia. The productivity of sorghum in India is $849.05 \mathrm{~kg} / \mathrm{ha}$, is well below the world's average (1444.6 kg/ha). In India, a total of $3.47 \mathrm{million}$ tons of sorghum grains were produced over the acreage of 4.07 million hectares during 2020 (FAO, 2021).In it is this ability to give a utile yield of grain under difficult agronomic conditions which makes sorghum such a valuable cereal (Satyagopal et al., 2014).

There are over 150 insect species known to damage sorghum plant from germination to crop harvest (Seshu Reddy and Davies, 1979). Insect-pests in sorghum cause nearly 32.0 per cent of the total loss to the actual produce in India (Borad and Mittal, 1983), 20.0 per cent in Africa and Latin America, 9.0 per cent in USA (Wiseman and Morrison, 1981). Added introduction of high-yielding hybrids of sorghum that is highly susceptible to shoot fly that induced the problem to become even more grievous situation (Jotwani 1981).

Among the insect-pests, the shoot fly (Atherigona soccata Rondani) is one of the most important and destructive pest which causes considerable losses in fodder as well as grain yield. Due to introduction of improved sorghum varieties and continuous cropping pattern, it has become a principal pest of the sorghum. This pest attacks on the sorghum crop at seedling stage causing maximum damage during the rainy season. The larva of this pest attacks on central whorl of the plant and causes dead heart formation. Various control tactics have been suggested for the management of this pest; however the sorghum crop grown early or timely can easily escape the incidence of this 
pest. Advancing different date of planting certainly returns good yield and, that also eliminates shoot fly attack; most sorghum pests can be avoided.

\section{Material and Methods}

A field experiment was carried out during crop season Kharif, 2018 and 2019at Research farm of CCS HAU, Regional Research Station, Rohtak (India). Sorghum variety, HJ 541, was sownon four different dates (15 June, 30 June, 15 July and 30 July) following the recommended agronomic practices (Anonymous, 2017) except the plant protection measures in randomized block design with five replications in plot size of $3 \times 5 \mathrm{~m}^{2}$. Incidence of shoofly was recordedat seedling stage on $14^{\text {th }}$ and $28^{\text {th }}$ day after crop emergence. At each observation, twenty-five plants were selected randomly from two middle rows from each plot and per cent incidence was calculated. The plants showing dead hearts were counted and removed to avoid recounting.

\section{Statistical analysis}

The data pertaining to incidence and seed yield were subjected to statistical analysis by using standard analysis of variance (ANOVA) as per procedures of Sheoran et al., 1998.

\section{Results and Discussions}

Plant resistance plays an integral part in integrated pest management of field crops. Simultaneously, it has become increasingly important to understand the interactions between insect-pests and host plants for building foundation of breeding programme for resistance. The data on shoot fly incidence and grain yield have been presented in table 1. The sorghum variety HJ 541 was tested for natural incidence of shoot fly, Atherigona soccata (Rondani) under field condition selecting four different sowing dates $\left(15^{\text {th }} \mathrm{June}, 30^{\text {th }} \mathrm{June}, 15^{\text {th }} \mathrm{July}\right.$ and $\left.30^{\text {th }} \mathrm{July}\right)$.

\section{At 14 days after emergence of sorghum crop}

There was significant difference in per cent of dead hearts due to the presence and or invasion of sorghum shoot fly when sown on $15^{\text {th }}$ June $(4.80 \%)$ compared to $15^{\text {th }}(13.60 \%)$ and $30^{\text {th }}$ July $(20.00 \%)$, while it was found at par when crop sown on $30^{\text {th }}$ of June $(7.20 \%)$ in Kharif season year 2018.

Per cent dead heart incidence caused by shoot fly was recorded minimum when sorghum crop sown on $15^{\text {th }}$ of June in crop year 2019i.e., 5.60 per cent that was at par with 8.0 per cent of $30^{\text {th }}$ June sown crop. Significant differences were apparent in number of dead hearts when crop sown on $15^{\text {th }}$ of June than $15^{\text {th }}(14.40 \%)$ and $30^{\text {th }} \mathrm{July}(23.20 \%)$ of crop season of Kharif, 2019. There were substantial differences in dead hearts when crop rose in field at $30^{\text {th }}$ July in both the Kharif season of year 2018 and 2019 as compare to crop when sown in field at dated $15^{\text {th }}$ and $30^{\text {th }}$ June and $15^{\text {th }}$ July.

\section{At 28 days after emergence of sorghum crop}

Although dead hearts caused by shoot fly was recorded minimum when sorghum crop sown at $15^{\text {th }}$ of June (7.20\%) that was found to be at par with crop sown on $30^{\text {th }}$ of June (12.00\%), but it differed significantly when crop sown on $15^{\text {th }}$ of July $(19.20 \%)$. However, sorghum crop sown on $30^{\text {th }}$ of June $(12.00 \%)$ found at par with crop sown on $15^{\text {th }}$ of July (19.20 \%) that differed significantly with crop of 30 July having 32.00 per cent dead heart in Kharif, 2018. 
Maximum numbers of dead heart (33.6\%) were observed when sorghum crop sown on $30^{\text {th }}$ of July while least number of dead heart recorded when crop planted on $30^{\text {th }}$ of June $(8.80 \%)$. Significant differences in number of dead hearts were registered when sorghum rose at distinctly separate fortnight interval. Moreover there was increasing trend in number of dead hearts as sowing date of crop is delayed from $15^{\text {th }}$ of June to $30^{\text {th }}$ of July.

Yield realized by crop sown at $15^{\text {th }}$ and $30^{\text {th }}$ June found to be at par in year 2018i.e., 10.85 and $9.07 \mathrm{q} / \mathrm{ha}$, respectively; however minimum of yield ( $2.42 \mathrm{q} / \mathrm{ha}$ ) obtained in crop sown on $30^{\text {th }}$ of July in Kharif 2018. Minimum yield ( $2.23 \mathrm{q} / \mathrm{ha}$ ) was obtained in crop when sown on dated $30^{\text {th }}$ of July in Kharif of year 2019, whereas maximum yield (10.79 q/ha) recorded in sorghum crop delayed. Significant differences in yield were apparent when crop is sown at different dates in Kharif 2019 year. It is to be learned in the present study that beyond $30^{\text {th }}$ June the incidence of shoot flies increased, while grain yield decreased significantly (Table 1).

Ameta and Sumeria (2004) also found that as the sowing of sorghum was delayed, the infestation of shoot fly increases and adversely affected the plant height, weight and length of earhead and grain yield. In an experiment, Pavani et al. (2019) concluded that the egg laying by the pod borer, Helicoverpa armigera decreased across sowing dates from October to December in chickpea crop. In maize, Ullahet al. (2010) registered minimum per cent infestation (1.39) in plot sown in the $3^{\text {rd }}$ week of July instead of plots sown in $2^{\text {nd }}$ week of July recorded the highest (4.82) suggests that the percent infestation of maize stem borer, Chilo partellus can be minimized by sowing the crop in mid July. Salman and Abdel-Moniem (2008) tested twenty maize hybrids against shoot fly incidence with respect to sowing dates may be maneuvered with a proper cultivating date for maize hybrids as it not only brought about reduction in infestation, but was also a good method to reduce insecticidal application to control shoot fly. Incidence and population fluctuation in variety of insect pests very much dependent on the prevailed climatic conditions of the cropping season in mung bean, thus insect pests attacking mung bean crop can be manipulated by sowing at different dates (Hossain et al., 2009).

Authors further added that early and late sown crops received higher pest infestation than mid sown crops. Kethran et al. (2014) also inferred that early sowing of chilli crop i.e., in January $15^{\text {th }}$ or January $30^{\text {th }}$ resulted in lower incidence of aphids, thrips, whitefly and fruit borer except mites and such low level of insect pest caused less crop injury which resulted in enhancing the green pod yield of chilli. Sathish et al. (2017) observed higher incidence of shoot fly in $15^{\text {th }}$ July to $1^{\text {st }}$ August (20.93\% dead hearts) sown proso millet crops, whereas low incidence $(0.59 \%$ dead hearts) was transcribed when crop sown on $1^{\text {st }}$ May.

Table 1. Effect of date of sowing on the incidence of shoot fly, Atherigona soccata

(Rondani) in sorghum crop

\begin{tabular}{|c|c|c|c|c|c|c|c|c|c|}
\hline \multirow{2}{*}{$\begin{array}{c}\text { Date of } \\
\text { sowing }\end{array}$} & \multicolumn{5}{|c|}{ Per cent incidence } & \multicolumn{3}{c|}{ Seed yield (q/ha) } \\
\cline { 2 - 9 } & $\mathbf{2 0 1 8}$ & $\mathbf{2 0 1 9}$ & $\begin{array}{c}\text { Pooled } \\
(\mathbf{2 0 1 8 - 1 9 )}\end{array}$ & $\mathbf{2 0 1 8}$ & $\mathbf{2 0 1 9}$ & $\begin{array}{c}\text { Pooled } \\
(\mathbf{2 0 1 8 - 1 9 )}\end{array}$ & $\mathbf{2 0 1 8}$ & $\mathbf{2 0 1 9}$ & $\begin{array}{c}\text { Pooled } \\
(2018-19)\end{array}$ \\
\hline \multirow{2yyyyyyyy}{*}{ 15 June } & $\begin{array}{c}4.80 \\
(12.51)\end{array}$ & $\begin{array}{c}5.60 \\
(13.57)\end{array}$ & 5.20 & $\begin{array}{c}7.20 \\
(15.23)\end{array}$ & $\begin{array}{c}8.80 \\
(17.09)\end{array}$ & 8.00 & 10.85 & 10.79 & 10.82 \\
\hline
\end{tabular}


Asian Journal of Applied Science and Technology (AJAST)

Volume 5, Issue 3, Pages 105-110, July-September 2021

\begin{tabular}{|c|c|c|c|c|c|c|c|c|c|}
\hline 30 June & $\begin{array}{c}7.20 \\
(15.23)\end{array}$ & $\begin{array}{c}8.00 \\
(16.16)\end{array}$ & 7.60 & $\begin{array}{c}12.00 \\
(19.98)\end{array}$ & $\begin{array}{c}13.20 \\
(21.10)\end{array}$ & 12.60 & 9.07 & 8.89 & 8.98 \\
\hline 15 July & $\begin{array}{c}13.60 \\
(21.58)\end{array}$ & $\begin{array}{c}14.40 \\
(22.06)\end{array}$ & 14.00 & $\begin{array}{c}19.20 \\
(25.81)\end{array}$ & $\begin{array}{c}21.6 \\
(27.63)\end{array}$ & 20.40 & 6.20 & 5.94 & 6.07 \\
\hline 30 July & $\begin{array}{c}20.00 \\
(26.40)\end{array}$ & $\begin{array}{c}23.20 \\
(28.69)\end{array}$ & 21.60 & $\begin{array}{c}32.00 \\
(34.35)\end{array}$ & $\begin{array}{c}33.6 \\
(35.39)\end{array}$ & 32.80 & 2.42 & 2.23 & 2.24 \\
\hline $\begin{array}{c}\text { C.D. } \\
\text { (p=0.05) }\end{array}$ & 4.62 & 3.28 & & 5.96 & 3.62 & & 2.50 & 0.88 & \\
\hline CV & 17.51 & 10.69 & & 17.92 & 13.73 & & 11.99 & 4.26 & \\
\hline
\end{tabular}

Figures in parentheses are square root transformation, DAE $=$ Days after emergence

\section{Conclusion}

Field experiment was conductedat CCS HAU, Regional Research Station, Rohtak during Kharif season of year 2018 and 2019 to know the effect of sowing dates on the incidence of shoot fly in sorghum. Made an endeavour to find out the suitable date of sowing to minimize the incidence of shoot fly in sorghum crop.

From the present study, it can be concluded that sorghum crop sowing at different dates can minimize the incidence of shoot fly. The information generated in present study reveals that sowing of sorghum in the month of June minimize the incidence of shoot fly and increase production efficiency besides safety to the environment.

\section{Acknowledgements}

All sort of assistance rendered by Director of Research, Chaudhary Charan Singh Haryana Agricultural University, Hisar, India for the above study is gratefully acknowledged.

\section{Declarations}

\section{Source of Funding}

This research did not receive any grant from funding agencies in the public, commercial, or not-for-profit sectors.

\section{Competing Interests Statement}

The authors declare no competing financial, professional and personal interests.

\section{Ethical Approval}

Not applicable.

\section{Consent for publication}

Authors declare that they consented for the publication of this research work.

\section{Availability of data and material}

Authors are willing to share the data and material according to relevant needs. 
Asian Journal of Applied Science and Technology (AJAST)

Volume 5, Issue 3, Pages 105-110, July-September 2021

\section{References}

Anonymous, (2017). Package of practices of Kharif crops. CCS Haryana Agricultural University, Hisar.

Ameta, O.P. and Sumeria, H.K. (2004). Effect of sowing dates on the incidence of insect pests and productivity of sorghum [(Sorghum bicolor (L.) Moench]. Indian Journal of Agricultural Research, 38 (4): 278-282.

Borad, P.K. and Mittal, V.P. (1983). Assessment of losses caused by pest complex to sorghum hybrid, CSH 5. In: B.H. Krishnamurthy Rao and K.S.R.K. Murthy (Eds.), Crop losses due to insect pests, Special issue of Indian Journal of Entomology. pp. 271-278. Entomological Society of India, Rajendranagar, Hyderabad, Andhra Pradesh, India.

Doggett, H., Starks, K.J. and Eberhart, S.A. 1970. Breeding for resistance to the sorghum shoot fly. Crop Sci.10. FAO 2021: http//www.fao.org/faostat/en/\#data (accessed on $19^{\text {th }}$ of June, 2021).

Hossain, MA; Prodhan, MZH and Sarker, M.A. 2009. Sowing dates: A major factor on the incidence of major insect pests and yield of mungbean. Journal of Agriculture Rural Development. 7(1 \& 2): 127-133.

Jotwani, M.G. 1981. Integrated approach to the control of the sorghum shoot fly. Insect Science and its Application. 2:123-127.

Salman, A.M.A. and Abdel-Moniem, A.S.H. (2008). Effect of planting dates and maize hybrids on the infestation with sorghum shoot fly, Atherigona soccata Rondani and its effect on the yield. Archives of Phytopathology and Plant Protection. 41(5): 349-359.

Sathish, R., Manjunatha, M. and Rajash ekarappa, K. 2017. Incidence of shoot fly, Atherigona pulla (Wiedemann) on proso millet at different dates of sowing. Journal of Entomology and Zoology Studies. 5(5): 2000-2004.

Satyagopal, K., S.N. Sushil, P. Jeyakumar, G. Shankar, O.P. Sharma, S.K. Sain, D.R. Boina, N. Lavanya, B.S. Sunanda, Ram Asre, R. Murali, Sanjay Arya, Subhash Kumar, H.S. Yadava, S. Lingaraju, R.N. Ganguli, M.P. Thakur, A.S. Kotasthane J.S. Mishra, V.K. Koshta, A.K. Awasthi, H. Ravindra, B.K. Shivanna, S. Gangopadhyay, V.R. Bhagwat, I.K. Das, S.T. Kajjidoni, B.R. Patel, L.V. Ghetiya, N. Sathyanarayana and S. Latha 2014. AESA based IPM package for Sorghum, 44pp.

Seshu, Reddy, K.V. and Davies, J.C. 1979. Pests of sorghum and pearl millet, and their parasites and predators, recorded at ICRISAT Center, India, upto August, 1979. Cereal Entomology Progress Report No.2. Patancheru, A.P. 502324, India: International Crop Research Institute for the Semi-Arid Tropics. 23pp.

Sheoran, O.P., Tonk, D.S., Kaushik, L.S., Hasija, R.C. and Pannu, R.S. (1998). Statistical software package for agricultural research workers. Recent advances in information theory, statistics and computer application by Hooda, D.S. and Hasija, R.C., Department of Mathematics and Statistics, CCS HAU, Hisar. 139-143.

Wiseman, B.R. and Morrison, W.P. (1981). Components for management of field corn and grain sorghum insects and mites in the United States. USDA Agricultural Research Service ARMS-18, Government Printing Office, Washington, DC, USA. 


\section{AJAST}

Asian Journal of Applied Science and Technology (AJAST)

Volume 5, Issue 3, Pages 105-110, July-September 2021

Muhammad, R. K., Ying Ying, S., Khan, S., Sana, U. B., Wu, L.L., Lu Yang Yang, T.T., Hu, Z., Salam, A., Iqbal, S., Ali, S. and Bashir, W.(2014). Effect of different sowing dates on insect pest population of chillies (Capsicum annuam L). Journal of Biology, Agriculture and Healthcare. 4: 196-208.

Pavani T., Ramesh B.T., Sridevi, D., Radhika, K. and Sharma, H.C. (2019). Effect of different sowing dates on pest incidence in chickpea. International Journal of Current Microbiology and Applied Sciences. 8: 627-637.

Ullah, F., S. Anwar, H. Badshah, M. A. Mashwani and M. H. Khan. 2010. Effect of different planting dates of maize on infestation of maize stem borer, Chilo partellus (swinhoe) pyralidae: Lepidoptera. Sarhad Journal of Agriculture. 26(4): 621-624. 